\title{
Demonstration of protein AA in subcutaneous fat tissue obtained by fine needle biopsy
}

\author{
PER WESTERMARK, BJÖRN STENKVIST, JACOB B. NATVIG, AND \\ ELISABETH OLDING-STENKVIST
}

From the Departments of Pathology, Clinical Cytology, and Infectious Diseases, University Hospital, Uppsalta and Department of Clinical Immunology, the Karolinska Institute, Stockholm, Sweden, and Institute Immunology and Rheumatology, the Rikshospital University Hospital, Oslo, Norway

SUMMARY Polarisation microscopy of material obtained by fine needle biopsy of subcutaneous tissue and stained with Congo red is a simple and reliable method for the diagnosis of systempe amyloidosis. It cannot, however, be used to differentiate histologically between different forms \&f amyloidosis. In the present study extracts of material obtained by fine needle biopsy of subcutaneous fat tissue from 13 patients were examined by double immunodiffusion with an antiserum againgt protein AA, a unique protein which forms a major part of the fibrils in secondary amyloidosis. Fi of the patients showed amyloid deposits round the fat cells by conventional microscopy. In 3 of these, all with rheumatoid arthritis, protein AA was detected. Eight patients without amyloidosis and $\vec{t}$ with myelomatosis and amyloidosis showed no reaction with antiprotein AA antiserum. Thus the material obtained by fine needle biopsy of subcutaneous tissue could be used not only for the hist logical diagnosis of amyloidosis but also for a classification of systemic amyloidosis into secondafy or primary based on the type of amyloid fibril protein involved.

At least 2 different classes of proteins of systemic amyloid fibrils exist. One class is derived from light chains of monoclonal immunoglobulin and is seen in primary amyloidosis and myeloma or macroglobulinaemia-Waldenström-associated amyloidosis (Glenner et al., 1971). The other class is protein AA, a previously unknown protein, which occurs mainly in secondary amyloidosis (Benditt et al., 1971). While the immunological cross-reactivity varies between the immunoglobulin-derived amyloid proteins, there is immunological identity between protein AA from different individuals by the immunoprecipitation techniques used.

In secondary amyloidosis the predisposing disease is usually evident. There are, however, cases in which the underlying disease is hidden. Since the elimination of the underlying diseases is the most important way to treat secondary amyloidosis, it is of great practical importance to know whether the amyloidosis is secondary or not.

The serum protein SAA is antigenically related to protein AA and occurs in low concentration in

Accepted for publication 29 March 1978.

Correspondence to Dr P. Westermark, Department of Pathology, PO Box 553, S-751 22 Uppsala, Sweden. normal serum (Benson et al., 1975b; Rosenthal and Franklin, 1975) but is present in increased conceg. trations in a variety of pathological conditions besides primary and secondary amyloidosis (Bensê. et al., 1975a; Husby et al., 1973; Husby and Natvis.; 1974; Rosenthal and Franklin, 1975). Since SAA frequently present in high concentrations in system amyloidosis both of primary and secondary types; the estimation of SAA concentration is of no heh్ in distinguishing between different types of amyloiæ:osis.

Recently, a new method utilising fine needle biopsy of subcutaneous fat tissue has been developed for the diagnosis of systemic amyloidosis (Westermank and Stenkvist, 1973, 1976). The aim of this investigation was to study the possibility of using the smat tissue biopsy fragments for immunochemical detee tion of amyloid protein AA typical of secondary amyloidosis by using specific antiprotein AA antio. sera.

\section{Material and methods}

PATIENTS

All patients referred over a period of time to the Department of Clinical Cytology for fine needide 
biopsy of the skin owing to their being clinically suspected of suffering from amyloidosis were included in the study. One patient with known myelomatosis and amyloidosis was to added this series. Fine needle biopsy of abdominal adipose tissue was performed as described previously (Westermark and Stenkvist, 1973, 1976). For microscopical investigation aspirated tissue was spread on glass slides, air dried, stained with alkaline Congo red (Puchtler et al., 1962), and examined in polarised light. Typical green birefringence was taken as evidence for amyloid. From 7 out of the 13 patients studied, serum was drawn in order to study the occurrence of the amyloid-related serum protein SAA.

\section{EXTRACTION OF FAT TISS UE}

Material from 1 or 2 aspirations was ejected in normal saline. It was then washed twice in that solution to remove serum. After that the fragments of fat tissue were collected carefully with a small spatula and put in a small test-tube to which $0 \cdot 1$ $\mathrm{ml} 0 \cdot 1 \mathrm{~N} \mathrm{NaOH}$ was added. The tubes were kept at room temperature overnight, and thereafter the solutions were neutralised by adding $0.01 \mathrm{ml} 1 \mathrm{~N}$ $\mathrm{HCl}$. The resulting degraded amyloid solutions (DAM) (Pras et al., 1969) were used for double immunodiffusion analyses.

\section{IMMUNOLOGICAL METHODS}

Amyloid fibrils were isolated by the method of Pras et al. (1968) from an amyloid-laden spleen obtained from a patient with amyloidosis secondary to rheumatoid arthritis. Degraded amyloid preparation was prepared as described (Pras et al., 1969). Antiamyloid protein AA antiserum was raised in a rabbit by injections with the DAM preparation. Furthermore, an antiserum against a primary amyloid protein of $\lambda \mathrm{IV}$ immunoglobulin light chain origin (Cornwell III et al., 1977) was used. The antisera were absorbed with small amounts of pooled human serum. Double immunodiffusion was performed in $1 \%$ agarose gel.

\section{Results}

The results of the light microscopical investigation and of the double immunodiffusion tests in the 13 patients are seen in Table 1 . Of the 13 patients 11 suffered from chronic inflammatory disease, while 2 had myelomatosis. Five had amyloid deposits as detected in the subcutaneous tissue by light microscopic investigation of preparations stained with Congo red. In all cases a typical green birefringence was seen in polarised light. The amounts of amyloid varied and were moderate in the 3 patients with rheumatoid arthritis showing it, while 1 of the patients with myelomatosis showed a heavy infiltration of amyloid between the fat cells. The diagnosis of amyloidosis was confirmed in 3 patients by rectal biopsy and in one at necropsy. No further biopsies were obtained from the fifth patient or from patients in whom the fine needle biopsies were negative for amyloidosis.

Protein AA as detected by anti-AA antiserum was found in 3 patients who all had secondary amyloidosis associated with rheumatoid arthritis (Table 1). The lines of precipitation obtained with anti-AA antiserum were clear and were identical with those of a reference DAM preparation from a case of secondary amyloidosis and of pure protein AA (Fig. 1). In contrast, no reaction with antiprotein $\mathrm{AA}$ was found in material obtained from the 2 patients with myeloma-associated amyloidosis or from the patients without amyloidosis (Fig. 1). No precipitation reaction was seen between material from the 5 amyloid biopsies and the anti $\lambda$ IV amyloid antiserum.

Table 1 Results of fine needle biopsy of subcutaneous fat tissue from patients with suspicion of amyloidosis

\begin{tabular}{|c|c|c|c|c|c|c|}
\hline \multirow[t]{2}{*}{ Patient no. } & \multirow[t]{2}{*}{ Diagnosis } & \multirow{2}{*}{$\begin{array}{l}\text { Amyloid in fine } \\
\text { needle biopsy }\end{array}$} & \multirow{2}{*}{$\begin{array}{l}\text { Amyloid diagnosis } \\
\text { confirmed by }\end{array}$} & \multicolumn{3}{|c|}{ Immunodiffusion results $^{2}$} \\
\hline & & & & \multicolumn{2}{|c|}{ Extract of biopsy material } & $\begin{array}{l}\text { Serum } \\
\text { SAA }\end{array}$ \\
\hline 1 & RA & - & NT 3 & - & NT & NT \\
\hline 2 & RA & ++ & NT & + & - & NT \\
\hline 3 & $\mathbf{R A}+$ osteomyelitis & - & $\mathbf{N T}$ & - & NT & + \\
\hline 4 & Osteomyelitis & - & NT & - & NT & + \\
\hline 5 & $\mathbf{R A}$ & - & NT & - & NT & NT \\
\hline 6 & Osteomyelitis & - & NT & - & NT & - \\
\hline 7 & Dermatomyositis & - & NT & - & NT & + \\
\hline 8 & RA & - & NT & - & NT & + \\
\hline 9 & Tuberculosis, uraemia & - & NT & - & NT & NT \\
\hline 10 & RA & + & Rectal biopsy & + & - & NT \\
\hline 11 & RA & + & Necropsy & + & - & - \\
\hline 12 & Myelomatosis & $++t$ & Rectal biopsy & - & - & - \\
\hline 13 & Myelomatosis & ++ & Rectal biopsy & - & - & NT \\
\hline
\end{tabular}

1 The degree of amyloid infiltration graded between + and.$+++{ }^{2}$ Reaction obtained with specific antiamyloid antisera. ${ }^{3}$ Not tested. 


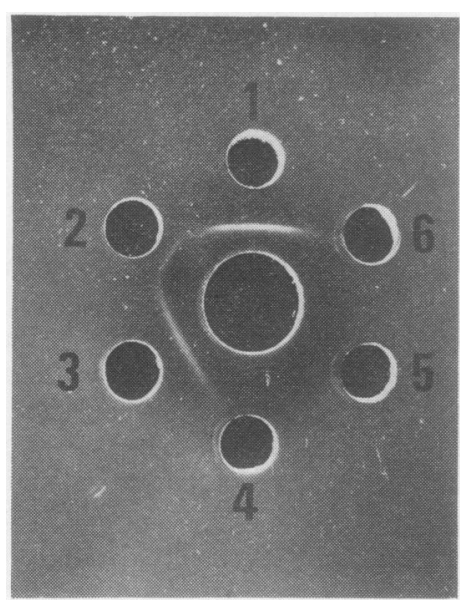

Fig. 1 Double immunodiffusion of antiprotein AA antiserum (central well) tested against a DAM preparation of a secondary amyloid (well 1), pure protein $A A$ (well 2), and extracts of fat tissue obtained by fine needle biopsy of patients 11 (well 3) and 12 (well 6). Buffer solution in wells 4 and 5.

Serum was available from 5 patients without amyloidosis, and serum protein SAA was detected in all these as well as in the serum from 1 of the patients with myeloma-associated amyloidosis. In serum from 1 of the patients with rheumatoid arthritis and amyloidosis protein SAA was not detected.

\section{Discussion}

Amyloidosis can be diagnosed by means of tissue biopsy. Rectal biopsy has been the most commonly used method. In our hands the fine needle biopsy of subcutaneous fat tissue has shown a good correlation with the finding of amyloidosis in rectal biopsy. The skin biopsy has also the advantage of being simpler to perform and more convenient to the patient.

Since the amounts of tissue obtained by fine needle biopsy are small, and there were only limited amounts of amyloid substance in the subcutaneous fat tissue in 3 of the patients, the material used in the immunodiffusion experiment were extracted with a small amount of alkaline solution. With this microtechnique, however, the precipitation lines obtained with antiprotein AA antiserum were clear in all cases. Thus the new technique appears to be fairly sensitive, and a heavy infiltration of amyloid in the fat tissue is not necessary for the demonstration of protein AA by this method.
The finding of protein AA in the DAM preparaz? tions of all 3 patients with secondary amyloidosis. due to rheumatoid arthritis was expected. However, protein AA is exceptionally also present in othe types of systemic amyloid (Benson et al., 1975a 흔 Husby et al., 1973), but in such cases an immunos

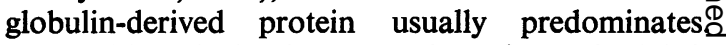
Thus, although the demonstration of protein AA is not absolutely diagnostic for secondary amyloidosis, it is highly suggestive of that type. The absence of protein AA in the fat tissue extract of the 2 patients with myelomatosis and amyloidosis is also consisten? with this.

The chemical classification of amyloid substances has hitherto been undertaken almost exclusively on post-mortem materials. Recently an immuno. fluorescence system for the classification of amyloiof proteins in situ has been developed, which is usefuP also for biopsies (Cornwell III et al., 1977). This $\vec{T}_{7}$ seems to be the method of choice when an exac믕 classification of an immunoglobulin-derived protein? is wanted. However, the immunofluorescence technique is complicated and requires considerable experience. Therefore as an alternative method â simple immunodiffusion test of extract of subcutaneous tissue obtained by fine needle aspiration is useful, especially to answer the question whether an amyloidosis is of secondary type or not.

Supported by grants from the Research Fund of the Swedisß Association against Rheumatic Diseases and the Norwegian $\vec{B}$ Rheumatic Council.

\section{References}

Benditt, E. P., Eriksen, N., Hermodson, M. A., and Ericsson L. H. (1971). The major proteins of human and monkey amyloid substance: common properties including unusua? $\mathrm{N}$-terminal amino acid sequences. FEBS Letters, 19? 169-173.

Benson, M. D., Skinner, M., and Cohen, A. S. (1975a) Antigenicity and cross-reactivity of denatured fibriT proteins of primary, secondary and myeloma-associatec5 amyloids. Journal of Laboratory and Clinical Medicine $D$ 85, 650-659.

Benson, M. D., Skinner, M., Lian, J., and Cohen, A. S $(1975 \mathrm{~b})$. 'A' protein of amyloidosis. Isolation of a cross reacting component from serum by affinity chroma
tography. Arthritis and Rheumatism, 18, 315-322.

Cornwell III, G. G., Husby, G., Westermark, P., NatvigN J. B., Michaelsen, T. E., and Skogen, V. (1977). Identi-fication and characterization of different amyloid fibrik proteins in tissue sections. Scandinavian Journal of Immus nology, 6, 1071-1080.

Glenner, G. G., Terry, W., Harada, M., Isersky, C., and? Page, D. (1971). Amyloid fibril proteins: proof of homo:logy with immunoglobulin light chains by sequenceanalysis. Science, 172, 1150-1151.

Husby, G., and Natvig, J. B. (1974). A serum componenh related to non-immunoglobulin amyloid protein $\mathrm{AS}$, aD possible precursor of the fibril. Journal of Clinical Invest $P$ gation, 53, 1054-1061. 
Husby, G., Natvig, J. B., Michaelson, T. E., Sletten, K., and Höst, H. (1973). Unique amyloid protein subunit common to different types of amyloid fibril. Nature, 244, 362-364.

Husby, G., Sletten, K., Michaelsen, T. E., and Natvig, J. B. (1973). Amyloid fibril protein subunit, 'protein AS': distribution in tissue and serum in different clinical types of amyloidosis including that associated with myelomatosis and Waldenström's macroglobulinaemia. Scandinavian Journal of Immunology, 2, 395-404.

Pras, M., Schubert, M., Zucker-Franklin, D., Rimon, A., and Franklin, E. C. (1968). The characterization of soluble amyloid prepared in water. Journal of Clinical Investigation, 47, 924-933.

Pras, M., Zucker-Franklin, D., Rimon, A., and Franklin, E. C. (1969). Physical, chemical and ultrastructural studies of water-soluble human amyloid fibrils. Comparative analyses of nine amyloid preparations. Journal of Experimental Medicine, 130, 777-795.

Puchtler, H., Sweat, F., and Levine, M. (1962). On the binding of Congo red by amyloid. Journal of Histochemistry and Cytochemistry, 10, 355-364.

Rosenthal, C. J., and Franklin, E. C. (1975). Variation with age and disease of an amyloid $\mathrm{A}$ protein-related serum component. Journal of Clinical Investigation, 55, 746-753.

Westermark, P., and Stenkvist, B. (1973). A new method for the diagnosis of systemic amyloidosis. Archives of Internal Medicine, 132, 522-523.

Westermark, P., and Stenkvist, B. (1976). The diagnosis of systemic amyloidosis by fine-needle biopsy of the skin. In Amyloidosis, p. 403. Edited by $\mathrm{O}$. Wegelius and $\mathrm{A}$. Pasternack. Academic Press: London. 